\title{
Heat Transport and Water Permeability during Cracking of the Landfill Compacted Clay Cover
}

\author{
Haijun Lu, ${ }^{1}$ Jianjun Liu, ${ }^{1,2}$ Yuan $\mathrm{Li}^{2}{ }^{2}$ and Yiqie Dong ${ }^{1}$ \\ ${ }^{1}$ Institute of Poromechanics, Wuhan Polytechnic University, Wuhan 430023, China \\ ${ }^{2}$ School of Geoscience and Technology, Southwest Petroleum University, Chengdu 610500, China \\ Correspondence should be addressed to Jianjun Liu; liujj0906@163.com
}

Received 27 July 2014; Revised 1 October 2014; Accepted 9 October 2014

Academic Editor: Peng Xu

Copyright (c) 2015 Haijun Lu et al. This is an open access article distributed under the Creative Commons Attribution License, which permits unrestricted use, distribution, and reproduction in any medium, provided the original work is properly cited.

\begin{abstract}
The heat-moisture transport through the compacted clay was observed in laboratory. The hydraulic conductivity of cracked clay under wetting-drying cycles was also investigated. At the early phase of heating, the temperature of soil columns rose fast and moisture decreased dramatically; after this phase, the temperature rose at a lower speed and moisture loss stabilized gradually. The moisture content of compacted clay at $25 \mathrm{~cm}$ depth decayed to 0 . The crack intensity factor (CIF) of compacted clay was 0.043 and 0.097 ; the crack depth was about $6.5 \mathrm{~cm}$ and $8.2 \mathrm{~cm}$ at $50^{\circ} \mathrm{C}$ and $60^{\circ} \mathrm{C}$, respectively. The hydraulic conductivity of compacted clay was within $8.3 \times 10^{-7}$ to $1.5 \times 10^{-5} \mathrm{~cm} / \mathrm{s}$ after four wetting-drying cycles. This value was $2 \sim 3$ orders of magnitude higher than that of uncracked clay.
\end{abstract}

\section{Introduction}

In order to reduce the generation of landfill leachate, a cover system, as an important part of the antiseepage structure, must be set when landfill reaches its maximum reserve. Compacted clay is recommended to be used for building the cover system structure and the hydraulic conductivity of the clay must be less than $1 \times 10^{-7} \mathrm{~cm} / \mathrm{s}[1]$. However, under the internal and external environmental effects, crack of the compacted clay cover system always occurs, which provides a convenient path for the infiltration of rainwater and then results in a sharp increase in landfill leachate which may take a severe toll on the ecological environment around the landfill.

Large amounts of heat are released by the degradation of solid waste, causing the rise of temperature in landfill. The temperature inside the landfill can go up to $70^{\circ} \mathrm{C}[2]$. Due to the temperature dependence of vapor density and the temperature gradient between the landfill and surrounding atmospheric environment, vapor diffuses upward and out of the compacted clay cover. This strongly enhances the downward transport of liquid water by gravity $[3,4]$. Therefore, vapor diffusion leads to the decrease in matric potential, causing the shrinkage and desiccation of compacted clay. When matric potentials become very small, the compacted clay shrinks horizontally and crack occurs [5-7]. For compacted clay cover systems with very low hydraulic conductivity, moisture will be slowly transported through landfill cover systems [8]. However, rainwater can directly leak into landfill if crack occurs in the compacted clay layer. Cracking leads to the changes of hydraulic conductivity (from $10^{-7}$ to $10^{-4} \mathrm{~cm} / \mathrm{s}$ ) and thermal conductivity of compacted clay $[9,10]$ and ultimately influences the heat-moisture transport in the cover system.

To investigate the surface cracking of soil columns and heat-moisture transport, the tests of heat-moisture transport through soil columns during cracking were conducted by the monitoring system of cracking. The permeability of compacted clay during wetting-drying cycles was measured with the PN3230M environmental soil flexible wall permeameter.

\section{Materials and Methods}

2.1. Materials. The clay used in the tests was taken from a construction site in Wuhan City of China. Basic physical properties and chemical composition of the clay are shown in Tables 1 and 2. 
TABLE 1: The physical properties of the clay.

\begin{tabular}{|c|c|c|c|c|c|c|c|c|}
\hline \multirow{2}{*}{$\rho_{d \max }\left(\mathrm{g} / \mathrm{cm}^{3}\right)$} & \multirow{2}{*}{$W_{\text {opt }}(\%)$} & \multirow{2}{*}{$W_{L}(\%)$} & \multirow{2}{*}{$W_{p}(\%)$} & \multirow{2}{*}{$I_{p}(\%)$} & \multicolumn{4}{|c|}{ Particle size distribution (\%) } \\
\hline & & & & & $>0.05 \mathrm{~mm}$ & $0.05 \sim 0.005 \mathrm{~mm}$ & $0.005 \sim 0.002 \mathrm{~mm}$ & $<0.002 \mathrm{~mm}$ \\
\hline 1.65 & 19 & 48.5 & 26.2 & 22.3 & 12 & 32 & 45 & 11 \\
\hline
\end{tabular}

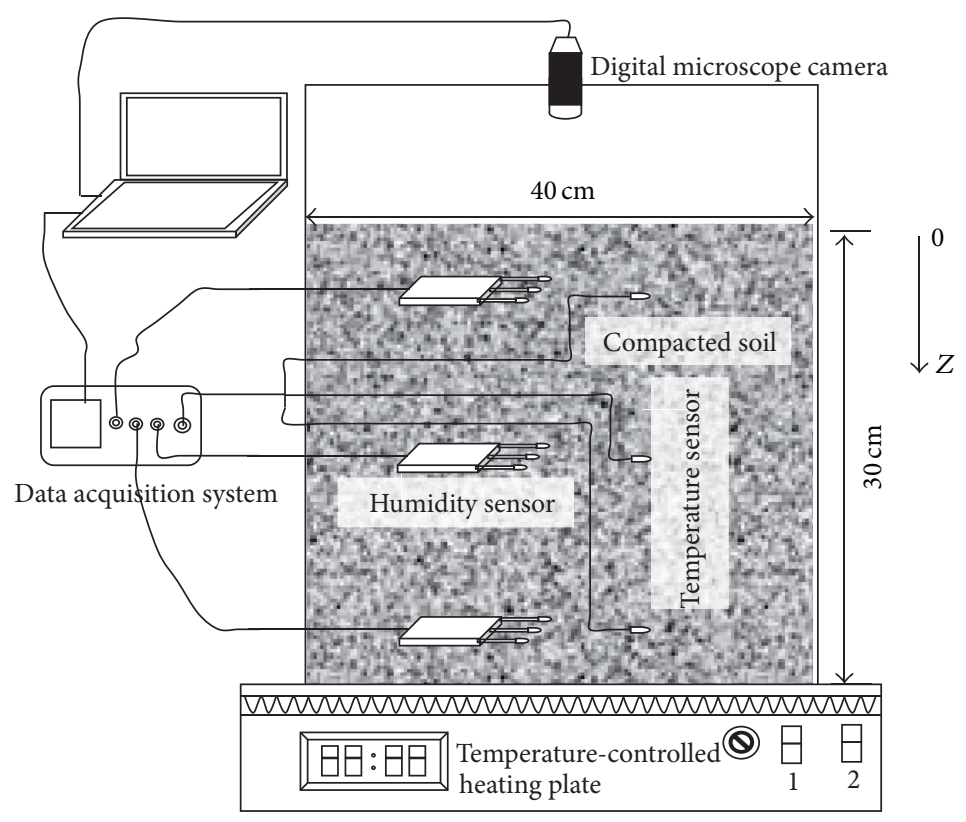

FIGURE 1: The monitoring system of cracking and heat-moisture transport in compacted clay.

TABLE 2: The chemical composition of the clay.

\begin{tabular}{lcccccc}
\hline $\mathrm{SiO}_{2}$ & $\mathrm{AL}_{2} \mathrm{O}_{3}$ & $\mathrm{Fe}_{2} \mathrm{O}_{3}$ & $\mathrm{CaO}$ & $\mathrm{MgO}$ & $\mathrm{K}_{2} \mathrm{O}$ & $\mathrm{Na}_{2} \mathrm{O}$ \\
\hline 58.42 & 25.23 & 0.24 & 0.51 & 0.12 & 5.32 & 2.67 \\
\hline
\end{tabular}

2.2. Methods. The soil and moisture were mixed evenly, put into soil columns, and then compacted layer by layer. The compacted soil layer was formed at the maximum dry density in the column. The height and diameter of the soil columns were $30 \mathrm{~cm}$ and $40 \mathrm{~cm}$, respectively. The bottoms of the soil columns were placed directly on the temperature-controlled heating plate $\left(50^{\circ} \mathrm{C}\right.$ and $\left.60^{\circ} \mathrm{C}\right)$, surrounded by the insulation pad to prevent the dissemination of heat. Temperature and humidity sensors were placed in the depth of $5 \mathrm{~cm}, 15 \mathrm{~cm}$, and $25 \mathrm{~cm}$ of the soil columns, monitoring temperature and moisture changes of compacted clay. A digital microscope camera was placed $50 \mathrm{~cm}$ above the soil column to observe the surface cracking (Figure 1).

The PN3230M environmental soil flexible wall permeameter, made by American GEOEQUIP, was used to test the permeability of the compacted clay under different wettingdrying cycles. The permeameter can prevent the sidewall leakage that might be caused by the specimen's volume change during the wetting-drying cycles. The specimen was initially sized at a diameter of $5 \mathrm{~cm}$ and a height of $5 \mathrm{~cm}$ for permeability tests. All samples were made by pressing soil of specific quantity into the cutting ring of the mentioned size.
The samples were placed in a vacuum saturator can for $48 \mathrm{hr}$ before permeability tests and then were placed in a dryer at $50^{\circ} \mathrm{C}$ for $72 \mathrm{hr}$ after permeability tests. The aforementioned steps were repeated for four wetting-drying cycles.

\section{Results and Discussion}

3.1. Heat-Moisture Transport of Cracked Clay. Temperature variation at different depths of soil columns showed similar patterns at the heating source of $50^{\circ} \mathrm{C}$ or $60^{\circ} \mathrm{C}$ (Figure 2). Early in the heating, temperature at different depths rose quickly but then the growth trend attenuated significantly and eventually stabilized. The temperature was close to $50^{\circ} \mathrm{C}$ or $60^{\circ} \mathrm{C}$ at the depth of $25 \mathrm{~cm}$ after $22 \mathrm{hr}$ of heating, indicating that the column bottom had cracks by now. The heat transport in soil columns was fast and able to achieve stability in a short time. Since the compacted clay layer can store heat, transport of heat in soil columns was significantly delayed with increasing distance from the heating source.

The soil moisture loss at various soil depths were given in Figures 3 and 4 . The soil moisture loss near the bottom was highly sensitive to heat loading, and the effect was significantly attenuated and time lagged along with increasing distance from the heating source. The testing results of the heating source of $60^{\circ} \mathrm{C}$ indicated that soil moisture loss was very rapid within the first $20 \mathrm{hr}$ and slowed down during 20 to $384 \mathrm{hr}$. Within $20 \mathrm{hr}$, at the depth of $25 \mathrm{~cm}$, 


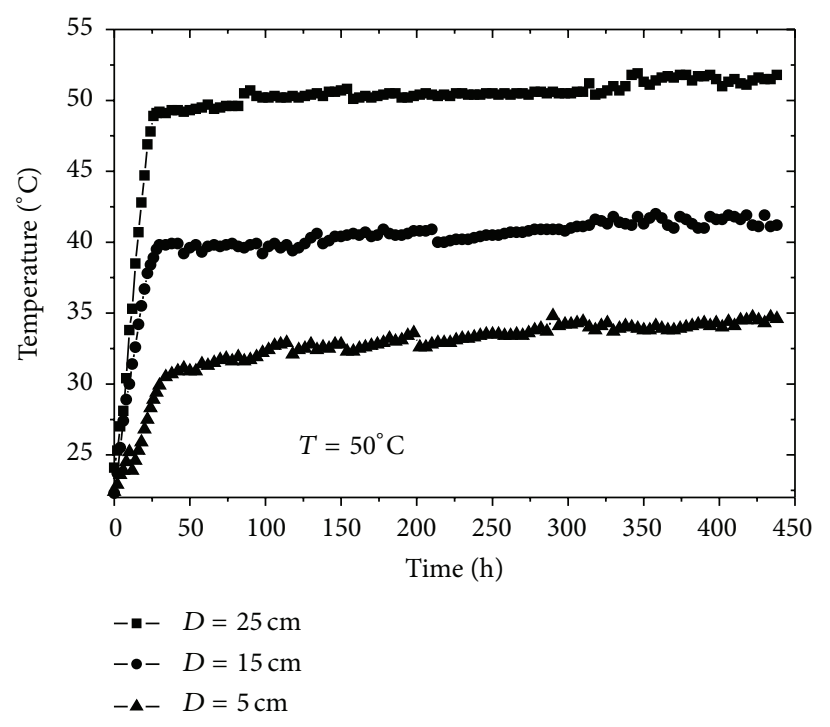

(a)

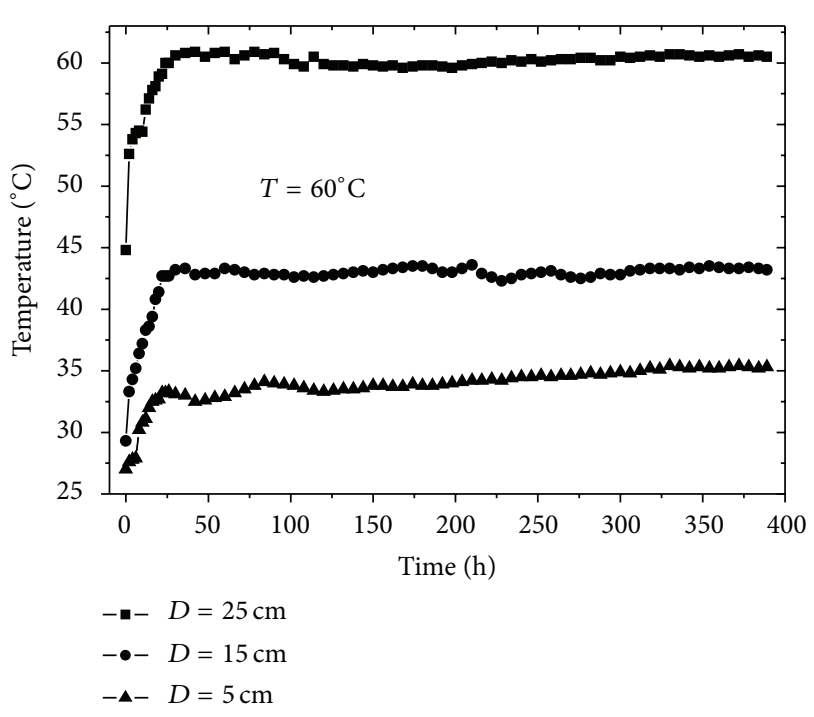

(b)

FIGURE 2: The temperature of compacted clay changes with time.

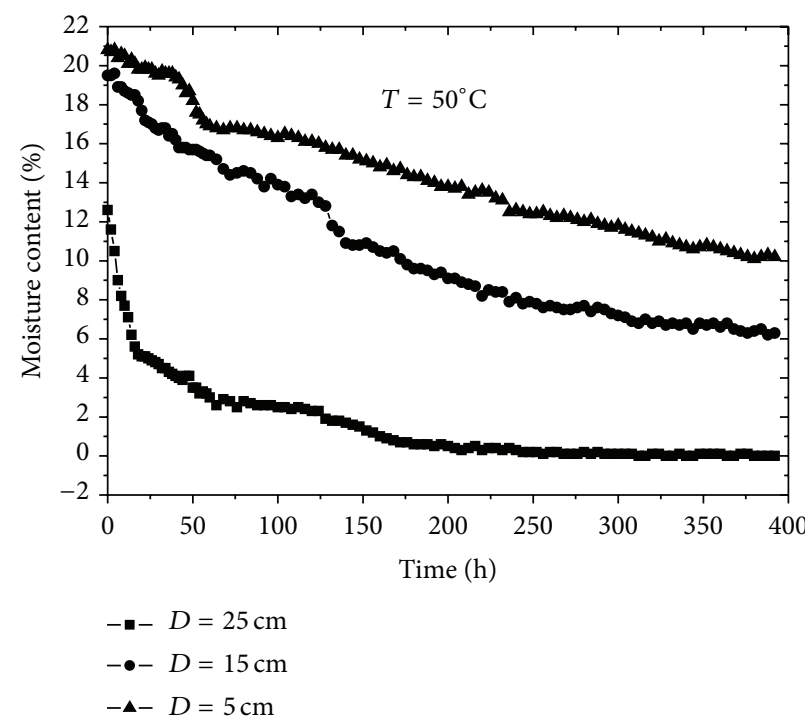

(a)

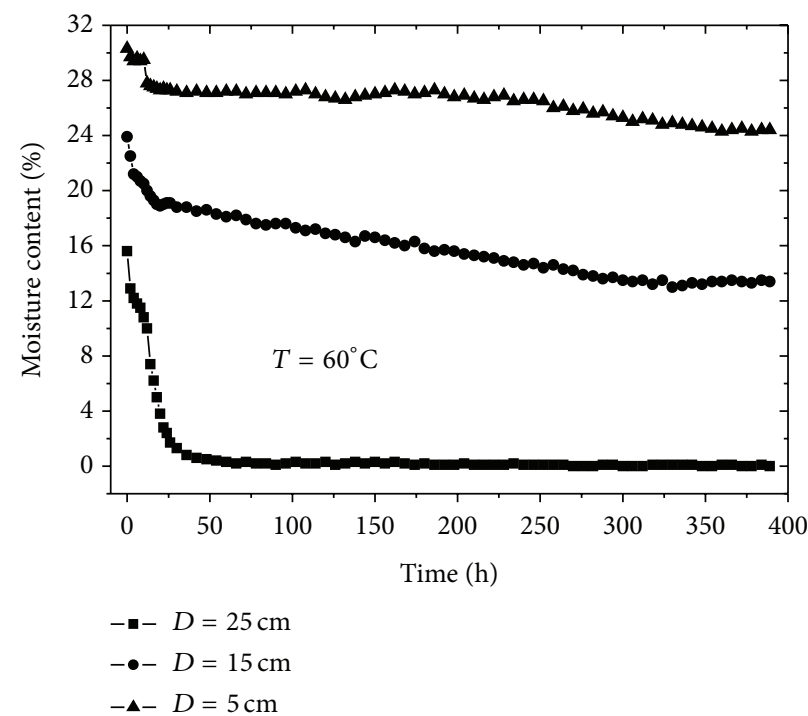

(b)

FIGURE 3: The moisture content of compacted clay changes with time.

the soil moisture content decreased from 0.16 to 0.038 . The temperature gradient between the clay layer and the heat source was great at the early heating, resulting in fast moisture transmission. However, the soil moisture content at the depth of $25 \mathrm{~cm}$ decreased gradually from 0.038 to 0 during 20 to $384 \mathrm{hr}$, owing to the lower temperature gradient.

The cracking of compacted clay was characterized by the cracking intensity factor (CIF). The CIF value was the ratio of the cracking area $\left(A_{c}\right)$ to the total area $\left(A_{t}\right)$ [11-13]. Comparing the cracked and uncracked part of the surface, the former was obviously dim. The CIF was calculated by using the digital microscopy image analysis software. The surface
CIF of compacted clay under heating source of $50^{\circ} \mathrm{C}$ or $60^{\circ} \mathrm{C}$ is shown in Figure 5. Compacted clay in the first 3-4 days showed no obvious cracks. Subsequently, the CIF increased dramatically from 0.0025 to 0.028 or from 0.0042 to 0.036 . Then the CIF increased slowly to 0.043 and 0.097 .

A kind of sticky black tracer was injected into soil columns to observe the crack depth. Soil material was colored in black at the tracer flow path. The crack depth was determined by the soil color change. After $4 \mathrm{hr}$, the soil column was cut along the cracking direction from top to bottom. It can be concluded that the surface crack depth of soils was about $6.5 \mathrm{~cm}$ and $8.2 \mathrm{~cm}$ at $50^{\circ} \mathrm{C}$ and $60^{\circ} \mathrm{C}$, respectively. 


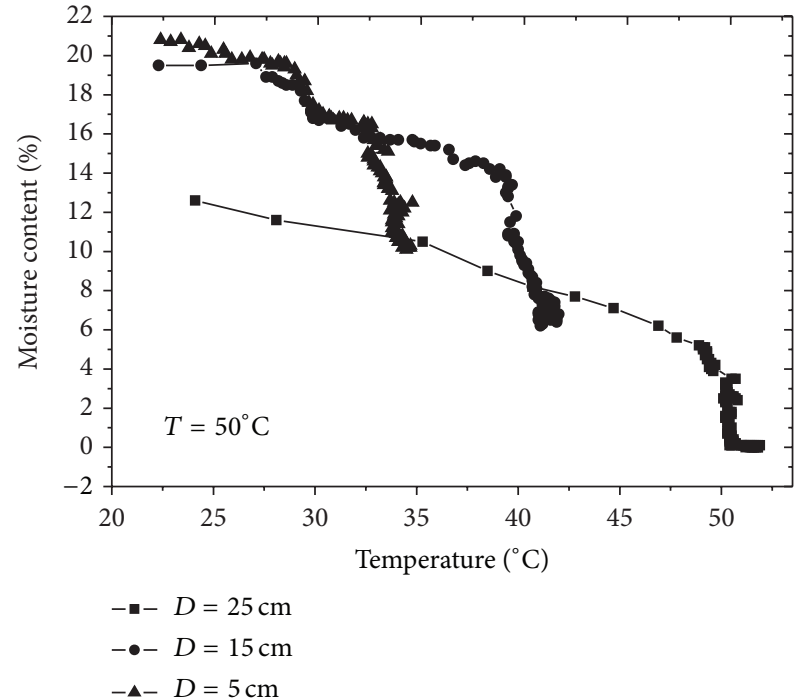

(a)

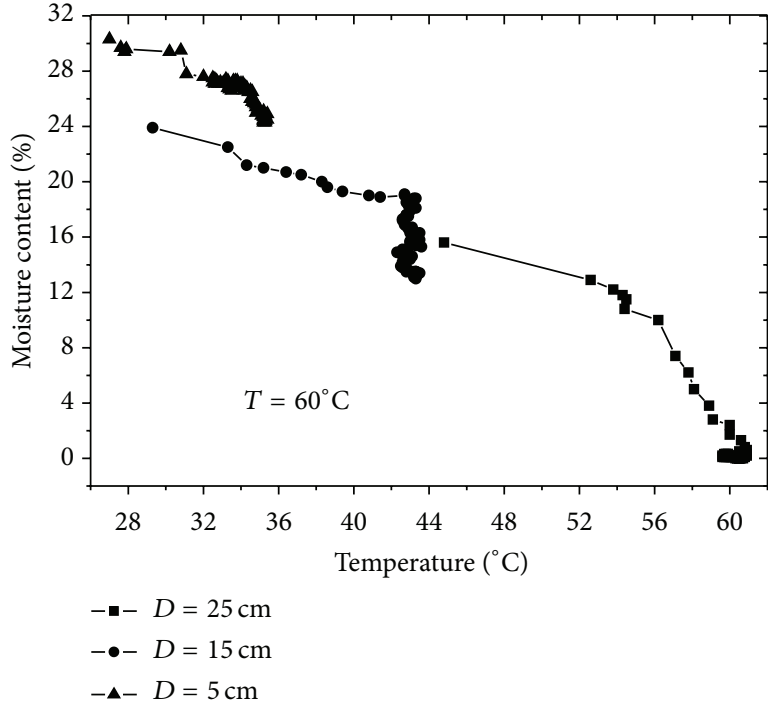

(b)

FIGURE 4: The moisture content of compacted clay changes with temperature.

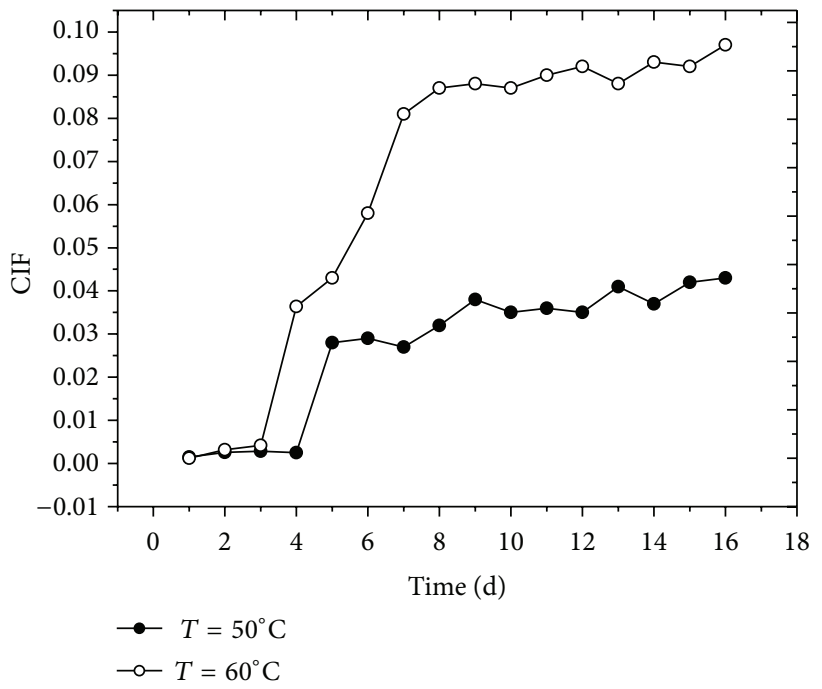

FIGURE 5: CIF of compacted clay under temperature gradient.

3.2. Hydraulic Conductivity of Cracked Clay. As shown in Figures 6 and 7, the influence of wetting-drying cycles on hydraulic conductivity of the compacted clay is remarkable. After four wetting-drying cycles, under the dry density $(\rho=$ $\left.1.65 \mathrm{~g} / \mathrm{cm}^{3}\right)$ and moulding moisture content $\left(w_{0}=0.25\right)$, the hydraulic conductivity of the compacted clay showed a significant increase, with its value jumping from $3.6 \times$ $10^{-8} \mathrm{~cm} / \mathrm{s}$ to $1.5 \times 10^{-5} \mathrm{~cm} / \mathrm{s}$. The hydraulic conductivity of the compacted clay $\left(\rho=1.65 \mathrm{~g} / \mathrm{cm}^{3}, w_{0}=0.21\right)$ increased from $2.5 \times 10^{-8} \mathrm{~cm} / \mathrm{s}$ to $8.3 \times 10^{-7} \mathrm{~cm} / \mathrm{s}$. The hydraulic conductivity of other samples is two orders of magnitude higher than that of uncracked soils. It was also observed that the hydraulic conductivity of compacted clay samples is close to equilibrium after three wetting-drying cycles. The cracks presented in the clay surface provided a path for water seepage after wetting-drying cycles.

\section{Conclusions}

The main purpose of the study was to observe the heatmoisture transport and water permeability of compacted clay during cracking of compacted clay. To fulfill this purpose, a series of tests of heat-moisture transport through soil columns during cracking were performed, and the hydraulic 


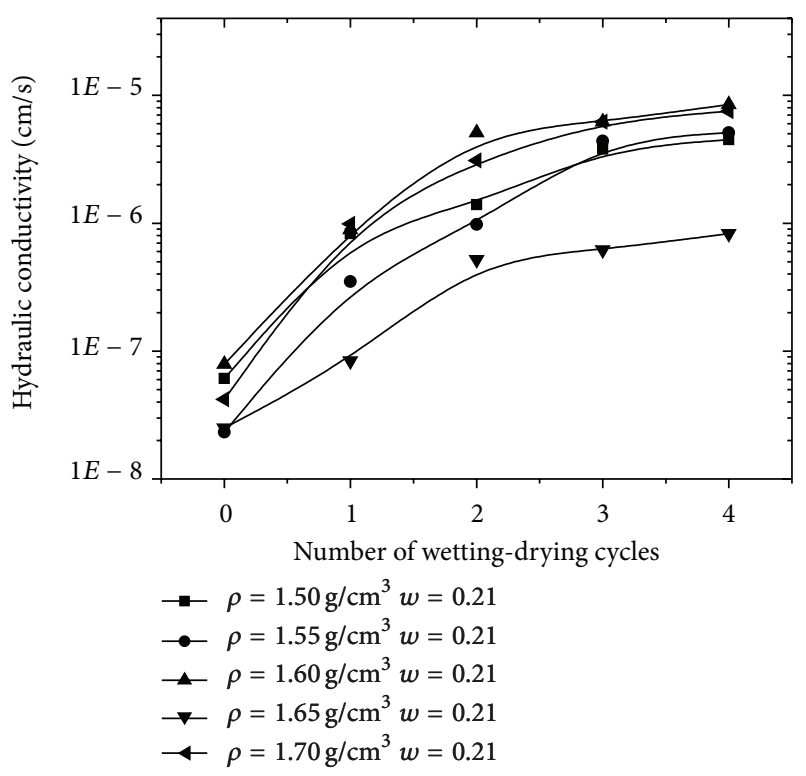

(a)

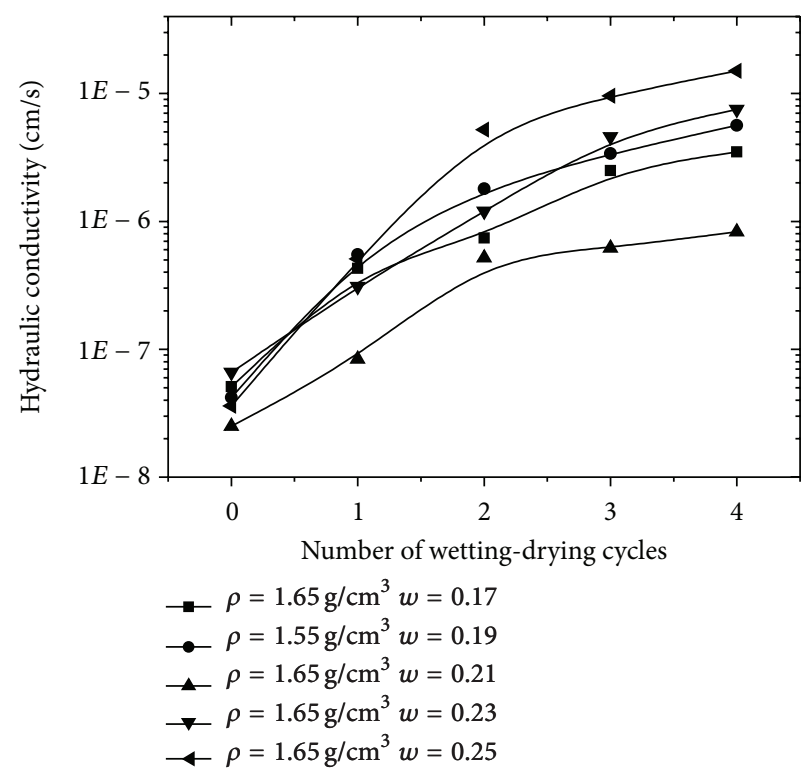

(b)

FIGURE 6: The hydraulic conductivity of compacted clay during wetting-drying cycles.

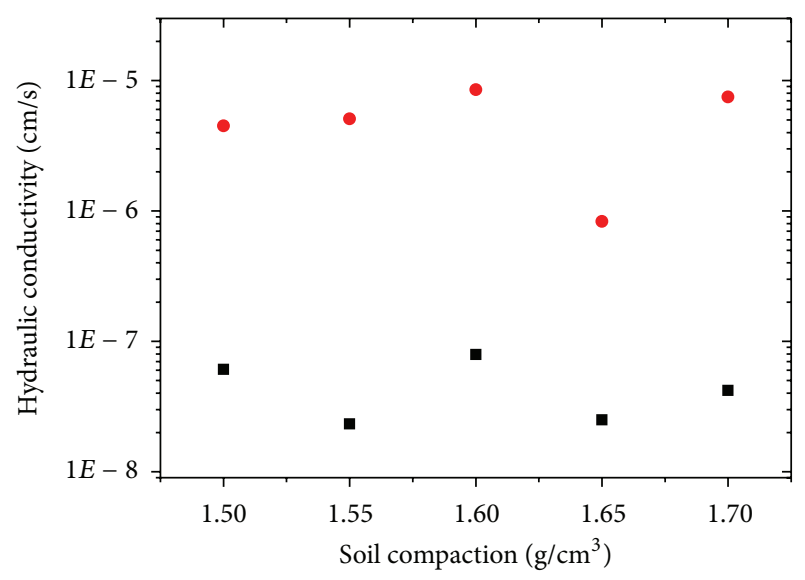

- Before wetting-drying cycles - After wetting-drying cycles

(a)

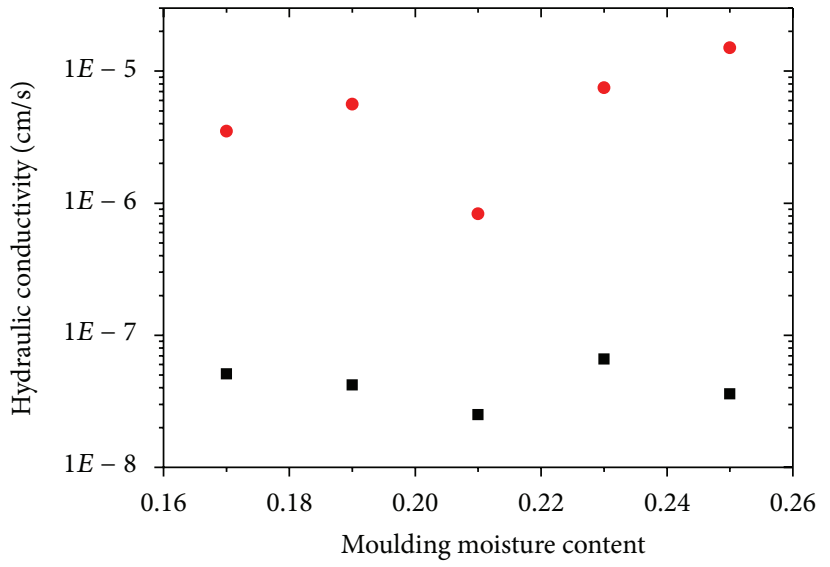

- Before wetting-drying cycles

- After wetting-drying cycles

(b)

FIGURE 7: The hydraulic conductivity of compacted clay before and after wetting-drying cycles.

conductivity of soil under different wetting-drying cycles was also investigated.

In the early phase of heating, the temperature of soil columns rose fast and the moisture loss was serious. The speed of temperature increased and then attenuated significantly, with a long period of slow dehydration. After heating for 16 consecutive days at $50^{\circ} \mathrm{C}$ and $60^{\circ} \mathrm{C}$, at the depth of $25 \mathrm{~cm}$, the temperature increased to $48.5^{\circ} \mathrm{C}$ and $59.1^{\circ} \mathrm{C}$ and the soil moisture content decreased to 0 . Cracks appeared at the surface of soil columns. The CIF was 0.043 and 0.097 and the crack depth was about $6.5 \mathrm{~cm}$ and $8.2 \mathrm{~cm}$, respectively.

After four wetting-drying cycles, the hydraulic conductivity of compacted clay was within $8.3 \times 10^{-7}$ to $1.5 \times 10^{-5} \mathrm{~cm} / \mathrm{s}$.
This value increased by 2 3 orders of magnitude compared to that of uncracked clay, suggesting that the compacted clay completely lost its antiseepage capability.

\section{Conflict of Interests}

The authors declare that there is no conflict of interests regarding the publication of this paper.

\section{Acknowledgments}

The authors would like to express their great appreciation of the funding provided by the National Natural Science 
Foundation of China (11002102 and 51474168) and Wuhan Youth Chenguang Program of Science and Technology (201271031419).

\section{References}

[1] China Architecture and Building Press, "Technical code for municipal solid waste sanitary landfill," CJJ 17-2004, China Architecture and Building Press, Beijing, China, 2004, (Chinese).

[2] R. Klein, T. Baumann, E. Kahapka, and R. Niessner, “Temperature development in a modern municipal solid waste incineration (MSWI) bottom ash landfill with regard to sustainable waste management," Journal of Hazardous Materials, vol. 83, no. 3, pp. 265-280, 2001.

[3] P. Döll, "Desiccation of mineral liners below landfills with heat generation," Journal of Geotechnical and Geoenvironmental Engineering, vol. 123, no. 11, pp. 1001-1009, 1997.

[4] Y. Zhou and R. K. Rowe, "Development of a technique for modelling clay liner desiccation," International Journal for Numerical and Analytical Methods in Geomechanics, vol. 27, no. 6, pp. 473-493, 2003.

[5] P. J. Hewitt and L. K. Philip, "Problems of clay desiccation in composite lining systems," Engineering Geology, vol. 53, no. 2, pp. 107-113, 1999.

[6] N. Lecocq and N. Vandewalle, "Dynamics of crack opening in a one-dimensional desiccation experiment," Physica A, vol. 321, no. 3-4, pp. 431-441, 2003.

[7] C. Basnett and R. Bruner, "Clay desiccation of a singlecomposite liner system," in Proceedings of the Geosynthetics'93 Conference, pp. 1329-1334, Vancouver, Canada, 1993.

[8] H. Lu, M. Luan, and J. Zhang, "Transport of Cr(VI) through clay liners containing activated carbon or acid-activated bentonite," Applied Clay Science, vol. 50, no. 1, pp. 99-105, 2010.

[9] S. Sadek, S. Ghanimeh, and M. El-Fadel, "Predicted performance of clay-barrier landfill covers in arid and semi-arid environments," Waste Management, vol. 27, no. 4, pp. 572-583, 2007.

[10] C. Bradley, M. Mosugu, and J. Gerrard, "Seasonal dynamics of soil-water pressure in a cracking clay soil," Catena, vol. 69, no. 3, pp. 253-263, 2007.

[11] H. Mi, Kinematic wave formulation for flow through macroporous soil [Ph.D. thesis], Department of Civil and Environmental Engineering, Wayne State University, Detroit, Mich, USA, 1995.

[12] C. J. Miller, H. Mi, and N. Yesiller, "Experimental analysis of desiccation crack propagation in clay liners," Journal of the American Water Resources Association, vol. 34, no. 3, pp. 677686, 1998.

[13] N. Yesiller, C. J. Miller, G. Inci, and K. Yaldo, "Desiccation and cracking behavior of three compacted landfill liner soils," Engineering Geology, vol. 57, no. 1-2, pp. 105-121, 2000. 

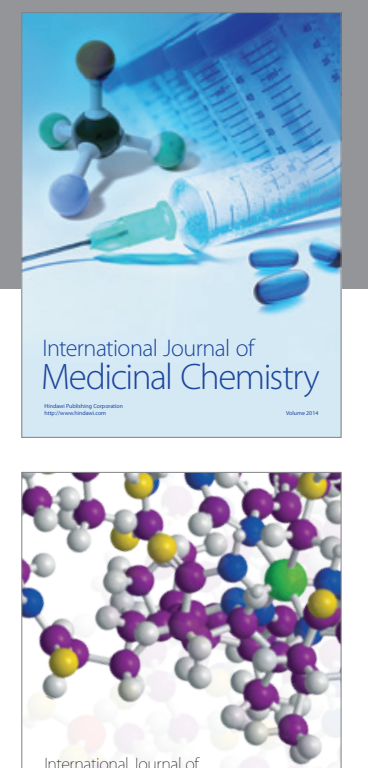

\section{Carbohydrate} Chemistry

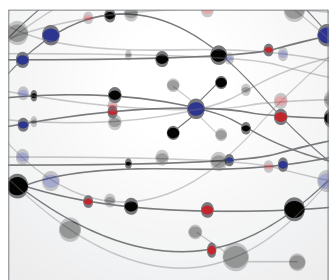

The Scientific World Journal
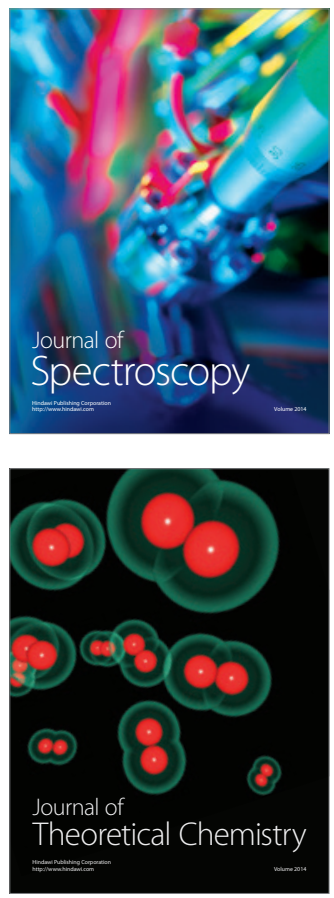
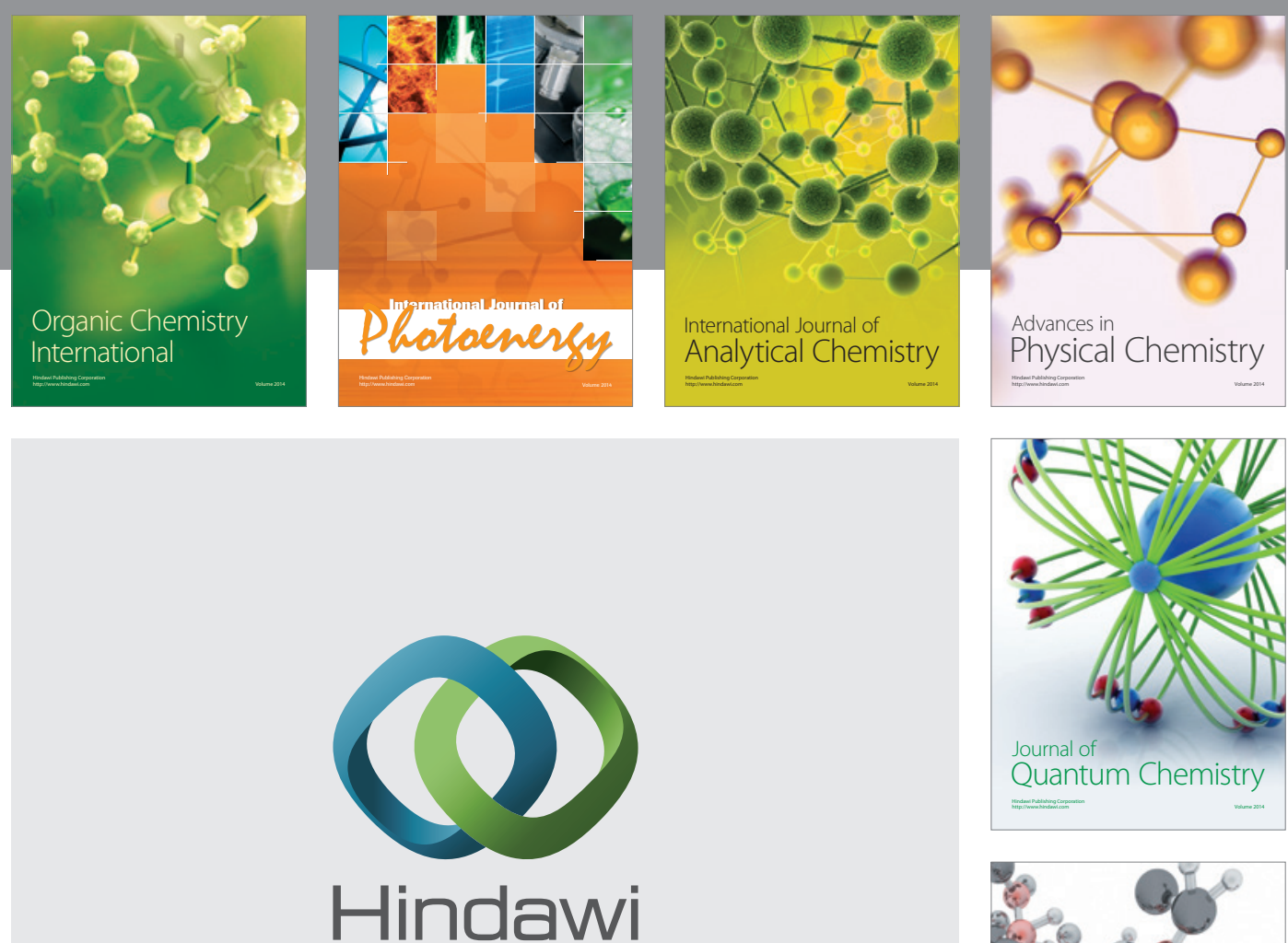

Submit your manuscripts at

http://www.hindawi.com

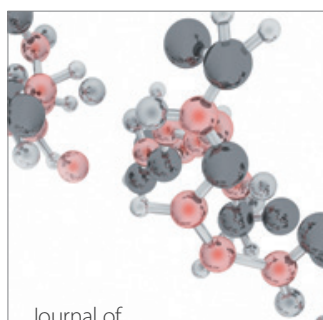

Analytical Methods

in Chemistry

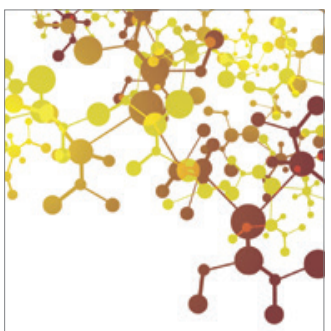

Journal of

Applied Chemistry

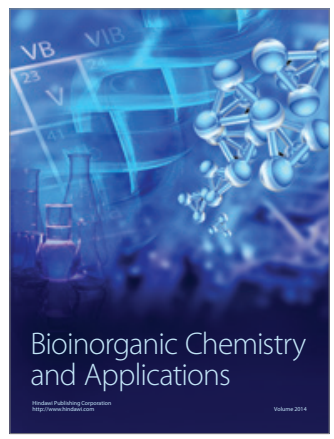

Inorganic Chemistry
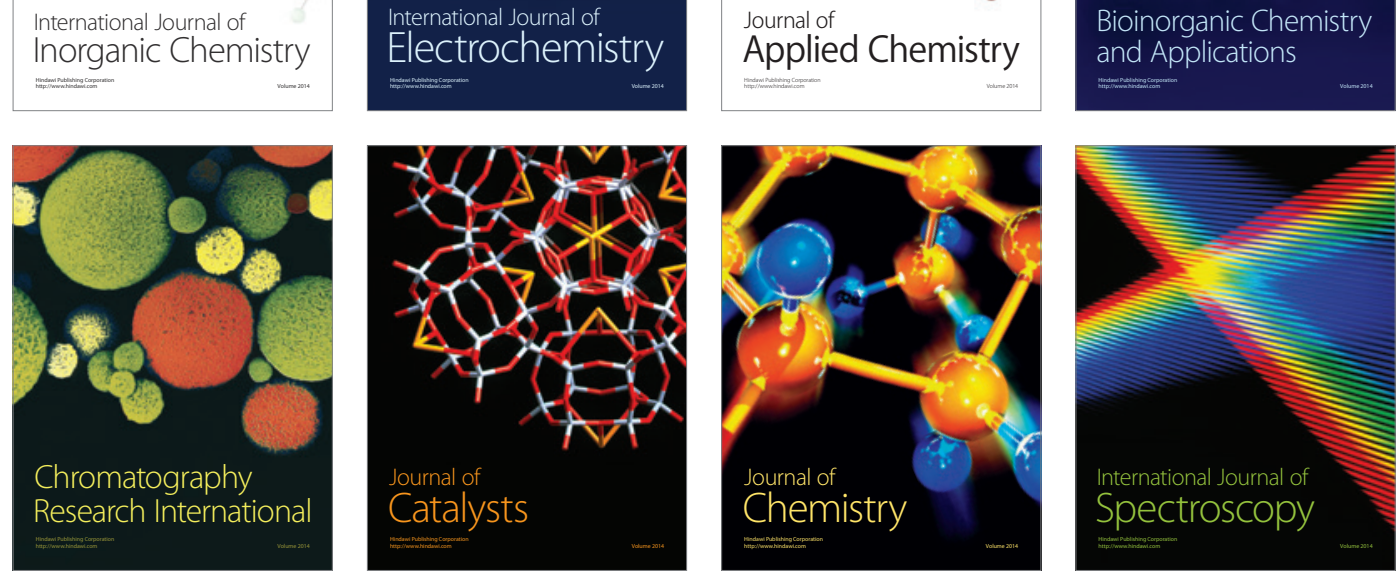